\title{
Commonwealth of Australia
}

\author{
John Wanna
}

\section{Turnbull's Bizarre Departure, and a Return to Minority Government for the Morrison-led Coalition}

Just when political pundits thought federal parliament could not become even wackier than it had been in recent times, the inhabitants of Capital Hill continued to prove everyone wrong. Even serious journalists began referring to the national legislature metaphorically as the "monkey house" to encapsulate the farcical behaviour they were obliged to report. With Tony Abbott being pre-emptively ousted from the prime ministership by Malcolm Turnbull in 2015, Turnbull himself was, in turn, unceremoniously usurped in bizarre circumstances in August 2018, handing over the leadership to his slightly bemused Treasurer Scott Morrison. Suddenly, Australia was being branded as the notorious "coup capital of the Western democracies", with five prime ministers in five years and only one losing the high office at a general election.

The course of Turnbull's demise was as irresistible as it was irreversible. Abbott and his conservative colleagues had never really accepted Turnbull's leadership and after the abysmal election campaign he had waged in 2016 had increasingly begun to question his political acumen and appeal to voters. By mid-2018 the Liberal right- wingers and other disgruntled dissidents were attempting to muster the numbers to unseat Turnbull, and a handful of simultaneous by-elections in late July provided a convenient catalyst - an opportunity not to be missed to remove Turnbull as PM.

Ironically, there was also a seriousness to the shenanigans that led to the eventual ascendancy of Scott Morrison as the new PM. Certainly, Turnbull's leadership was brought down by the conservative Liberals, but the leadership challenge did not go to plan and the attempt to replace Turnbull with a hard right stalwart like Peter Dutton backfired incredibly. In the end Morrison ended up in the top job almost accidentally due to a rear-guard action conducted by the Liberal moderates to replace Turnbull with his loyal

Treasurer. Publicly, there was never a plausible reason given for the leadership change and, despite Labor's continual taunting over the next few months over the lack of a rationale, one could only conclude that the latest "coup" was a case of venal backstabbing.

\section{Five By-elections on "Super Saturday"}

As mentioned in the previous chronicle, the High Court had declared Labor's Australian Capital Territory Senator Katy Gallagher ineligible, which triggered further resignations on Labor's side including Justine Keay (Braddon), Susan Lamb (Longman) and Josh Wilson (Fremantle), as well as Rebekha Sharkie (Mayo) from the Xenophon-Centre Alliance. Also Labor's Tim Hammond (Perth) had unexpectedly resigned for family reasons. The resulting 
five lower house by-elections, called "Super Saturday", were held simultaneously on 28 July. With the Liberals not standing candidates in the two Western Australian seats, campaigning for the other three by- elections took on an almost "presidential" character, much to the cost of the Liberals. Prime Minister Turnbull erroneously framed the Longman by-election as a head-to- head leadership contest, between himself and Opposition leader Bill Shorten, ostensibly to show his own electability as the Liberal leader. He famously visited the electorate in mid-July and rashly announced that the by-election in Longman was a "contest between me and Bill Shorten as the Prime Minister and the Opposition leader" (Sydney Morning Herald, 29 June 2018). He clearly hoped to make Shorten's apparent unpopularity centre-stage in the local campaign as part of a "kill Bill strategy", with the media hyping up the prospects of Anthony Albanese becoming the new Opposition Leader.

Yet on the Saturday evening as the votes were being counted, Labor was claiming its candidate Susan Lamb had received 40 per cent of the primary vote whilst the LNP vote had tanked to the mid-20s. This initial Labor lead prompted LNP president Gary Spence to claim that Turnbull was so unpopular in Queensland that Coalition MPs should back Peter Dutton if there was a leadership spill in the coming weeks. With Abbott sidelined, Dutton had emerged as one of the key leaders of the federal Liberals' right-wing faction who barely tolerated Turnbull, and he chose to magnify the poor result for the Liberals as a trigger for an internal political response. Labor's candidate recorded a slight swing of just under 3.7 per cent in Longman and Justine Keay managed an even more modest swing of 0.1 per cent in Braddon. None of the other seats fell the government's way; Rebekha Sharkie was comfortably returned in Mayo, and Labor held the Western Australian seats without much effort. The poor result for the government, especially in the neighbouring seat of Longman was cited by Dutton as a major reason for his doomed tilt against Turnbull.

\section{The Bizarre Fallout from the By-elections - a Leadership Revolt}

In the aftermath of the by-elections, which governments usually expect to lose, Turnbull was left to face the wrath of the right-wing of his party, goaded by News Corp journalists and the cabal of right-wing commentators on Sky TV over his leadership failure and poor campaign skills. An air of disaffection spread among the senior Coalitionists in Canberra with the Home Affairs Minister, Peter Dutton, chief among the complainants. Dutton came to the view that an alternative Coalition leader could do better and so began allowing numbers to be counted in the event a leadership challenge eventuate. Publicly Dutton professed loyalty to Turnbull, but his factional lieutenants (such as Tony Abbott, Eric Abetz, Greg Hunt, Mathias Cormann, Mitch Fifield, Steve Ciobo, Michael Keenan, Michaelia Cash, Alan Tudge, James McGrath and Angus Taylor) began mobilising like-minded colleagues canvassing his leadership prospects with Industry Minister Greg Hunt as his deputy on a conservative leadership ticket. It was even alleged that media mogul Rupert Murdoch had told Kerry Stokes that "Turnbull had to go" (ABC News, 9 November 2018), adding "three years of Labor wouldn't be so bad" (SBS News, 9 November 2018). 
Dutton's challenge was initially stymied by Turnbull expeditiously calling an immediate leadership spill as parliament resumed on Tuesday morning of 21 August 2018, and at the resulting party room meeting Turnbull survived by a vote of 48-35 (effectively a seven vote margin), with most attention being paid not to Turnbull's winning margin but to the high number of votes for the challenger. Dutton then resigned from the ministry and over the next couple of days other senior ministers resigned from Turnbull's government including Hunt, Ciobo, Keenan, Tudge and Concetta Fierravanti-Wells (but only Dutton's and Fierravanti-Wells's resignations were accepted). The closeness of the result encouraged the conservatives to try a second challenge, but Turnbull insisted that another only be called if a majority of Liberals indicated publicly that they wanted a further spill. Channel Nine news reported on Wednesday 22 August that it had been shown a letter (a petition) signed by MPs wanting a second ballot to determine the leadership, attempting to secure forty-three signatures (a majority of the federal Liberal members). The second ballot was triggered mainly because Mathias Cormann and his cabinet colleagues Cash and Fifield transferred their support to a Dutton challenge at the last minute, despite Cormann publicly supporting Turnbull the previous day (plus a few others like Warren Entsch signed to help clear the air).

At the second leadership tilt on Friday morning the motion to spill the leadership team was carried 45-40 votes meaning Turnbull's leadership was terminal. Three contenders then challenged for the leadership - Dutton, Julie Bishop and Morrison - with the ballot being held lunchtime on Friday 24 August. Despite being lauded as the party's "celebrity rock star", Julie Bishop was eliminated at the first round with a dismal score of just eleven votes, attracting none from her Western Australian colleagues. Morrison eventually defeated Dutton 45 votes to 40 to become Australia's thirtieth PM, with some media reports claiming he had been planning the coup for some months. Josh Frydenberg became deputy leader and Treasurer, relegating Bishop to the backbench. Although the revolt had been a huge kerfuffle of self-obsession, Turnbull reflected that he was "impressed by how many of his colleagues had spoken or voted for loyalty above disloyalty, how the insurgents were not rewarded" (ABC News, 25 August 2018). Nevertheless, some female colleagues complained of "bullying" over the ballot as factional players attempted to secure sufficient votes for their preferred protagonists, leading Julie Bishop to describe the behaviour as "appalling", and another MP Julia Banks (roundly dubbed an "insignificant" "lightweight backbencher") to quit the party altogether and announce she would not recontest her seat. Overall, the tumultuous week in federal politics led to many claims of continuous "political chaos in Canberra", with some sardonically observing: "another day, another spill".

\section{Another Reshuffle of "Truce"?}

A total of nine cabinet members out of twenty-three survived in their present posts in Morrison's initial cabinet. The major winners and promotions were Marise Payne to Foreign Affairs, Simon Birmingham to Trade, Tourism and Investment, Christopher Pyne to Defence, Kelly O'Dwyer to Jobs and Industrial Relations (replacing Michaelia Cash who was demoted to Small Business, Skills and Vocational Education but retained in cabinet), Dan Tehan to Education, and Paul Fletcher to Families and Social Services. Three new cabinet ministers 
were announced: Melissa Price (Environment), Angus Taylor (Energy) and Karen Andrews (Industry, Science and Technology). Other promotions included: David Coleman was given Immigration, Citizenship and Multicultural Affairs (separating it partially from Home Affairs), and Alan Tudge was moved to Cities, Urban Infrastructure and Population. Dutton supporters who retained their portfolios included: Dutton himself, Cormann, Hunt, Fifield, Matt Canavan, and Zed Seselja. Demotions were handed out to John McVeigh, Steve Ciobo and Michael Keenan who retained his Human Services portfolio but was dropped from cabinet. Julie Bishop decided herself to quit the ministry and went somewhat miffed to the backbench.

Once installed as PM, Morrison immediately began to craft a different image to his leadership than that exuded by the patrician and merchant banker Turnbull. Adopting the "down-to-earth" nickname "ScoMo" he played footy, drank beer in pubs, wore baseball caps, and repeatedly referred to his many pronouncements as "fair dinkum" promises. The image make-over immediately paid off with Newspolls and other polls putting Morrison well ahead of Shorten as preferred prime minister and in satisfaction levels with his performance increasing to a lead of 45-34 per cent (Newspoll, 8 December 2018).

\section{Parliamentary Pantomimes - "yes she is... no she isn't"}

In October a leak from Employment Minister, Senator Michaelia Cash's office was provided to TV stations about impending raids on two state offices of the Australian Workers' Union (AWU) by the Australian Federal Police (at the behest of the workplace relations regulator, the Registered Organisations Commission (ROC)). The leak was designed to feature the AWU search warrant raids in the full glare of media attention, so as to embarrass or discredit Bill Shorten who was a former AWU official. As national secretary, Shorten had authorised a $\$ 100,000$ donation in 2006 to the leftish activist group GetUp!, and the ROC raid was mounted to find documentation as to whether the donation was properly authorised. While nothing much improper was found in the raid, the leak severely embarrassed Cash and her ministerial advisers, and after Cash had many times denied to a Senate committee that she had authorised or known about the leak, two of her advisers later admitted to having knowledge, and her media adviser David de Garis soon chose to resign, followed by three other staffers who left her office under a cloud. Further evidence of who leaked to journalists came out in a subsequent civil action brought by the AWU against the ROC and, although Cash made a statement in parliament and an appearance in court, she continued to deny involvement; although a rash of defamation cases were initiated by and against the AWU, and social media outlets such as Buzzfeed.

In other evidence of the degeneration in parliamentary standards, Senators David Leyonhjelm and Sarah Hanson-Young got into a personal slanging match in a debate ostensibly over women's safety and the availability of pepper spray. At one point in the somewhat trivialised Senate debate, Leyonhjelm yelled out that if Hanson-Young believed all men were rapists then "she should stop shagging men". Hanson-Young took issue and called him a "creep" to which he told her to "fuck off". He refused to withdraw his remarks, 
and when asked by the Senate President refused to apologise. A bitter defamation case was then fought in the federal court which simply gave more airplay to the depths of disreputable parliamentary behaviour. Then, in August Labor's Emma Husar was accused by Buzzfeed of being a "slut" who boasted about having indiscriminate sex with men, had had sex with other MPs, often made sexually suggestive comments, and had "flashed" colleague Jason Clare imitating actress Sharon Stone in Basic Instinct - a claim both denied. These salacious claims followed other accusations that Husar had mistreated her staff and made them perform menial housekeeping duties such as cleaning her home, babysitting and picking up dog turds when walking her dog. The judge hearing the libel case sagely counselled the litigants that mediation might be advisable and that if the case was to go to trial "a lot of collateral damage might be done to a whole lot of people!". An internal ALP investigation into staff bullying headed by John Whelan from New South Wales Labor inquired into the forty-four allegations, finding evidence of offensive behaviour and acting unreasonably towards staff. Husar claimed the complaints were motivated by people in her local branch anxious to unseat her in her electorate of Lindsay, but she announced in August that she would not recontest her seat because of the "slut shaming" that she had received (but then appeared to change her mind about resigning before New South Wales Labor formally dis-endorsed her).

\section{Policy Merry-go-rounds}

\section{The Demise of NEG}

The National Energy Guarantee bill was a proposed piece of legislation designed to curb rising energy prices and make electricity production more reliable for consumers by forcing producers to draw from a mix of sources (by investments in low emissions energy) that could complement each other in times of peak demand or if system failures occurred. The energy guarantee was the outcome of the Energy Security Board which was established to implement the review conducted by Australia's Chief Scientist, Alan Finkel, and was linked to the clean energy target. The Turnbull government had failed to convince the Coalition of the merits of a clean energy target, so that proposal was embarrassingly publicly scrapped as was the NEG on 21 August immediately before the leadership change. Morrison then opted for an energy-lite policy using the ACCC report of the Retail Electricity Pricing Inquiry to announce in October he would introduce a price capping scheme to protect consumers, offer more choice of suppliers, and provide for tougher penalties for suppliers gaming the system.

\section{The Drought Crisis}

With mounting evidence most of eastern Australia was again in the grip of a major drought, Morrison worked towards a "new" National Drought Agreement (NDA) to go through COAG. He established a Joint Agency Drought Taskforce in his department and appointed MajorGeneral Stephen Day as its coordinator-general supremo, along with making Barnaby Joyce 
a special envoy for drought, thereby lifting his profile. In December the NDA was agreed between the Commonwealth and States, establishing a Future Drought Fund (around \$3.9 billion but only allocating $\$ 100$ million per annum, mainly for research), encouraging greater preparation for drought and improved management responses, farm loans and better targeted farming household financial support. Although the plan was spun as a "new" agreement, the National Farmers' Federation was critical of its lack of imagination, while Labor called it a "cut and paste job" of previous band-aid agreements.

\section{Institutional Turbulence - the banks and $A B C$}

The Banking Royal Commission was slowly and methodically trawling through a long list of topics and public hearings examining instances of not just poor practice but indefensible behaviours of the major banks, the AMP and the mortgage brokering system. Dispossessing farmers who had fallen into debt (one of the triggers of the royal commission) was soon displaced by a much more forensic legal investigation into wider banking practices (but not necessarily always informed by financial and economic analysis). Commissioner Hayne released an interim report in September covering the misconduct discovered in four areas of banking (lending, financial advice, loans to small business and banking in regional and remote communities) and was critical of the performance of ASIC and APRA for adopting soft approaches to regulation and lax enforcement. Meanwhile, a brouhaha exploded at the $A B C$ in September after some internal tensions between the board and the managing director, Michelle Guthrie, over governmental attacks on the dubious quality of the work of some ABC political journalists (Emma Alberici and Andrew Probyn) and some pressures to sack them. $A B C$ chair Justin Milne and a few other board members agreed to sack a "devastated" Guthrie without much public explanation but citing her "leadership style" and poor morale as factors in her removal. She had been asked to resign but refused and countered by claiming that Milne had referred to her as "the missus" and had been attempting to interfere with the $A B C$ 's editorial independence and trying to have the two journalists dismissed because the "government hated them" (ABC News, 27 September 2018). Fairfax media reported that Milne had in fact emailed Guthrie to demand the journalists be sacked and to "shoot" and "get rid of " them. Given the "firestorm" that the sacking had created amid allegations of political interference, Milne himself was forced to resign by the other board members (and $A B C$ staff) on 26 September, leaving no other alternative but to appoint an acting manager, David Anderson, while the corporation prepared to advertise for a new replacement. In responding to some external criticism the $A B C$ stated that the new MD would also be "editor-in-chief", ultimately responsible for all the content published by the corporation. Senior government members denied any interference had taken place, but a variety of alleged "conversations" continued to appear in other media platforms. 


\section{The Slide back to Minority Government - an Independent captures Wentworth}

With Malcolm Turnbull resigning almost immediately from parliament, a by- election was necessitated for his Sydney eastern suburbs seat of Wentworth and held on 20 October. Under pressure to preselect a female candidate, the Liberals nevertheless pre-selected former diplomat Dave Sharma to replace the former member - a candidate Turnbull did not warmly embrace or campaign for. In all, sixteen candidates stood for the by-election, including Labor, the Greens, a variety of single-issue independents and micro-party candidates plus celebrity doctor Kerryn Phelps (who was assisted in her campaign by experienced Labor party operatives). Prominent issues in the campaign included refugees held offshore, health funding, the establishment of a national integrity commission, the political disarray of the government, and claims the Liberals had "problems with women". Labor's candidate effectively "ran dead" and received only 11.53 per cent of the vote.

Despite Sharma recording 43.08 per cent of the primary vote, he received only 20 per cent of the subsequent preference flows, meaning Independent Kerryn Phelps won the seat with a primary vote of 29.20 per cent. On a two-candidate basis Phelps won the closely contested ballot by just 1,850 votes or 51.22 per cent to 48.78 per cent. Both Phelps and Sharma indicated that they would recontest the next general election to be held in 2019. With two sitting weeks of parliament remaining before the end of the year adjournment, Phelps engineered a private member's bill introduced into the Senate first to allow for offshore detainees who claimed refugee status and who were suffering mental health problems or other health illnesses to be transferred to the mainland for treatment (certified by two doctors). The bill which became known as the Medevac Bill was widely interpreted as a bid to undermine the government's hard stance on border protection and provide for a flow of asylum seekers who could claim transfer on medical grounds. The bill had to wait until into the New Year for it to be presented to the House of Representatives, where it was passed by a single vote in February and all cross-benchers except Bob Katter voting with Labor to secure its passage. The passing of the Medevac bill was a major defeat for the government; a phenomenon that had rarely occurred in the federal parliament since federation. 